\title{
4章 バイオメディカル用イメージセンサ
}

正会具笹川清隆 ${ }^{\dagger}$, 春田牧人门, 竹原浩成 ${ }^{\dagger}$, 竹原宏明 ${ }^{\dagger}$ 野田俊彦 ${ }^{\dagger}$, 正会員德田崇 ${ }^{\dagger}$, 正会員太田 淳 ${ }^{\dagger}$

キーワード：CMOSイメージセンサ, バイオイメージング, 蛍光観察, 生体埋植デバイス

\section{1.まえがき}

バイオメディカル分野において, 多くの場合イメージセ ンサは顕微鏡と組合せて利用されている.イメージセンサ の感度向上技術は, 微弱な蛍光の観察などの用途において も重要な役割を果たしている。ささらに，イメージセンサお よび光学系を専用に設計することによって, 高機能化, 高 性能化が実現され, 通常のイメージセンサでは困難なイ メージングが可能となる。本稿では, バイオメディカル応 用を目的としたセンサ技術について述べる。

\section{2. 蛍光観察用イメージセンサおよびデバイス}

蛍光観察に向けたイメージセンサの方向性としては, 微 弱な蛍光を観察するための高感度化, 蛍光寿命観察用セン サ, 光学系の簡易化を可能とする波長分離検出センサなど が挙げられる。

高感度化については, 近年のCMOSイメージセンサにお ける感度向上やノイズ低減技術の進展を背景にCCD と同等 以上のSN比をもち, 高速撮像可能なカメラが製品化されて きている. 最近の画素内増幅技術の進展から, 今後, EMCCD と同等以上の性能が実現されることも期待される ${ }^{1) \sim 5)}$.

\section{1 蛍光寿命観察}

緑色蛍光タンパク質 (Green Fluorescent Protein: GFP) など，バイオイメージングで用いられる蛍光体は, 数ナノ 秒程度で減衰する物が多い。 そのため，これに対応する高 速な変化の検出が可能なセンサが必要となる。 ただし, 繰 り返し照射されるパルスレーザ光などを励起光として用い ることができるため, 純粋な高速撮像ができる必要はない. このような用途では, 単一光子アバランシェダイオード (Single Photon Avalanche Diode: SPAD) 画素や高速に応 答感度を変調できる画素をもつイメージセンサが報告され ている.

†奈良先端科学技術大学院大学
"Image Sensors for Biomedical Applications" by Kiyotaka Sasagawa,
Makito Haruta, Hironari Takehara, Hiroaki Takehara, Toshihiko Noda,
Technology, Nara)

SPADによる画素は，フォトダイオード (PD) に大きな 逆バイアスをかけ，アバランシェ効果によって入射光信号 を増幅し, 高感度に検出するデバイスである.ナノ秒より も充分に短い時間での高速応答が可能であり, 光感度を持 つ期間を制御できるため，励起光であるレーザパルスが充 分減衰し, ほぼ蛍光のみがセンサに到達している時間のみ 光検出を行うことで, 蛍光寿命測定が可能となる ${ }^{6)}$ 7).

静岡大学では, 画素内の電界を能動的に制御することに よって, 画素内での電荷転送の流れを高速に制御する手法 に取組んでおり, 蛍光寿命計測などに応用可能なセンサを 実証している ${ }^{8)}$ １1).これらの手法はSPAD と比較して画 素毎の制御回路が簡素なもので良いため, 高い空間分解能 での計測が実現される.

\section{2 波長分離検出センサ}

波長分離検出センサは, 蛍光観察における光学系を単純 化し，デバイスの小型化を目的としたものである。 センサ 自体が励起光と蛍光の波長を分離して検出できるため, 光 学系のフィル夕を簡略化あるいは不要とすることができ る. 基本原理は, 波長によってセンサを構成するシリコン の透過率が異なることを利用している。このような原理を 用いた波長分離手法は, 比較的以前より提案されており, 積層フォトダイオード構造をもつ市販製品も存在する ${ }^{12)}$.

豊橋技科大は，フォトダイオード上に配置したポリシリコ ン層を介して, 電界を印加することにより空乏層の深さを 変調させ, 波長感度を制御する手法を提案している13) 16). この手法では, 感度特性を電圧制御することが可能である ため, 複数の波長に対応できる. 波長分離性能としては, $10^{3}: 1$ に近い值が報告されている ${ }^{16)}$.

奈良先端大では，CMOSイメージセンサプロセスを用いた 多層フォトダイオード構造をもつ画素を試作している ${ }^{17)}$. この画素では, 埋め込みフォトダイオードやNch MOSト ランジスタのLDD (Lightly Doped Drain) で使用される低 濃度 $\mathrm{N}$ 型層を使って多層フォトダイオード構成した。レイ アウト図と断面図を図1に示す。断面図は $\mathrm{A}-\mathrm{A}^{\prime}$ に沿っ た断面は，それぞれ，下層フォトダイオード (PD) から転 送ゲート, B-B’に沿った断面は, 上層 PDから転送ゲー 


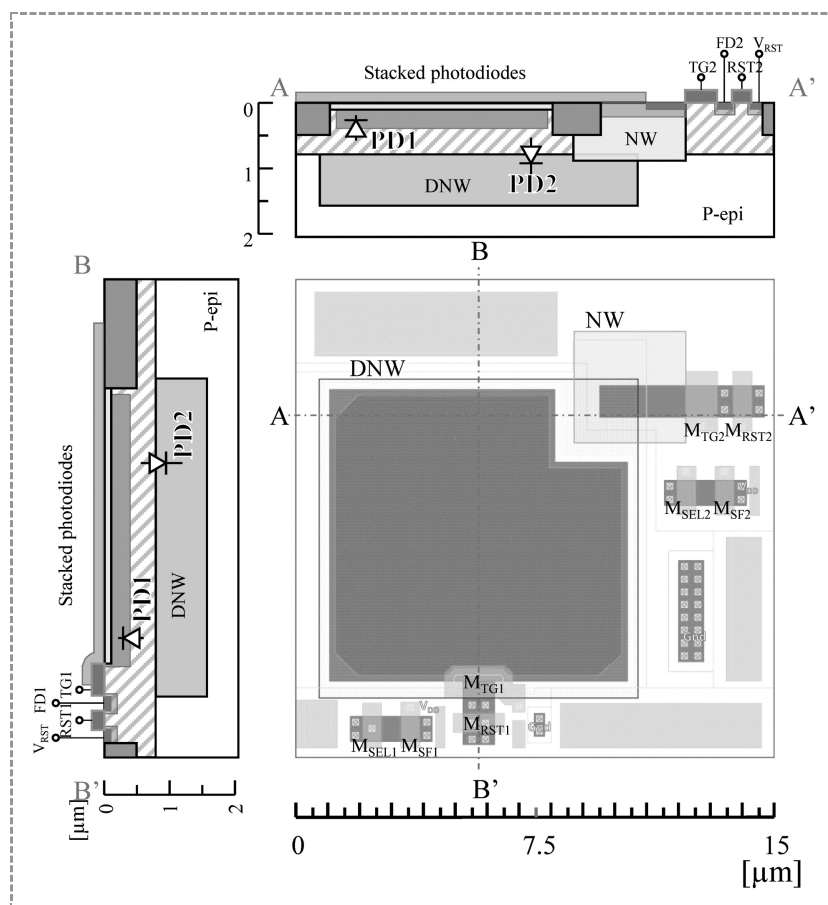

図 1 イメージセンサプロセスによる積層フオトダイオード搭載画素 レイアウトと断面図 (スケールの単位は $\mu \mathrm{m}$ )

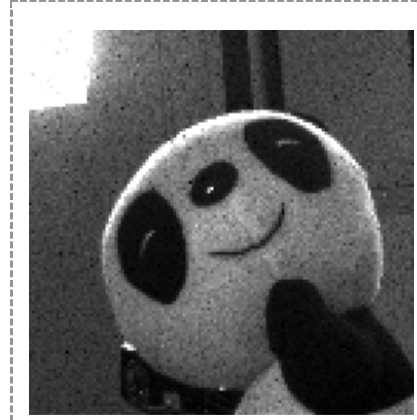

(a) 上層 $\mathrm{PD}$

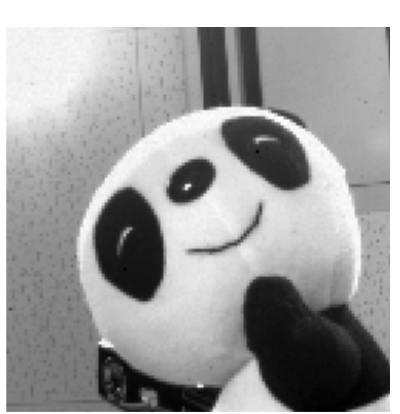

(b) 下層 $\mathrm{PD}$

図2 試作した積層フォトダイオード画素による撮像例

トの断面を表している.

試作したセンサを用いた撮像例を図2に示す（10 fps の動 画撮影)。また，中心波長 470 および $525 \mathrm{~nm}$ の 2 色の LED を励起光㧍よび蛍光に見立て, それぞれの LED 光強度に対 する上層PD と下層PDの画素值の変化を図3に示す. 波長 によって二つのPDの傾きが異なることから波長分離が可 能であることがわかる. また, それぞれの出力が, 光強度 に対して比例していることから, 両者の空乏層が分離され ており, 異なる梁さに到達したフォトンをそれぞれ検出で きていることを示している.

\section{3 応用例：ディジタルELISA用デバイス}

ELISA (Enzyme-Linked Immunosorbent Assay) は抗原 抗体反応の特異性を利用し, 酵素反応に基づく発色・発光 を観察することで, 特定の抗原の量・種類を検出可能な手

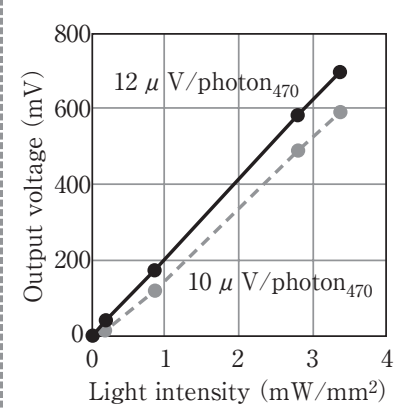

(a)

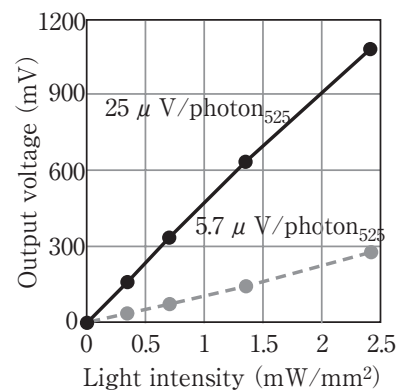

(b)
図3 照射光強度に対する画素出力

照射波長(a) $470 \mathrm{~nm}$ ，(b) $525 \mathrm{~nm}$. 破線は上層PD，実線は下層PD。

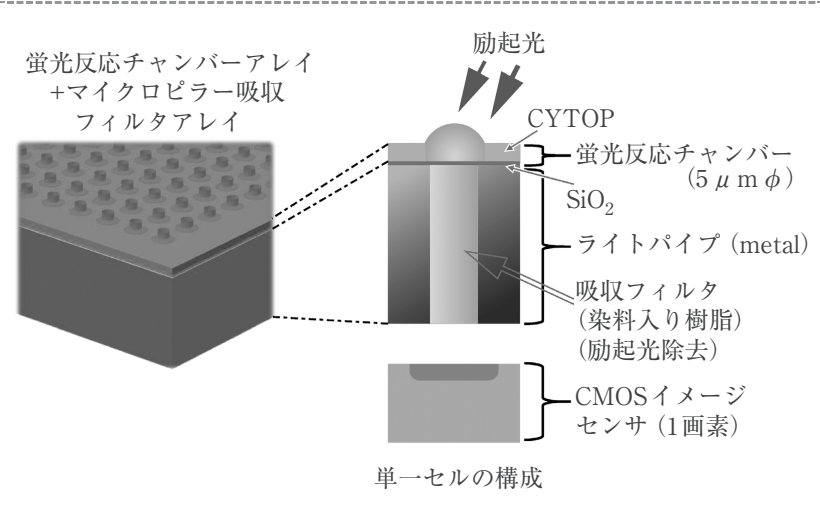

図4 マイクロピラー吸収フィルタアレイと蛍光反応チャンバーアレ イの構成

法である。しかし，従来のELISAは微量の観察対象分子の 検出を目的とした場合，飛躍的な検出感度の向上が必要と される。

ディジタルELISAは, 検出感度向上を目的とし, 反応 チャンバとして容積が $\mathrm{fL}$ 程度以下の微小なドロップレット チャンバを多数用いたものである ${ }^{18)}{ }^{19)}$. 微小な反応チャン バを用いることにより，観察対象の物質 1 分子に由来する 酵素反応の結果として生成される蛍光物質を観察すること が可能となる。これは，観察対象分子の濃度をアナログ的 な輝度值ではなく，蛍光を発するチャンバの数としてディ ジタル的な計数の結果として得ることができることを意味 している.これにより通常のELISA と比較して飛躍的な高 感度化が実現される。 Kimらは, 本手法を用いて $2 \mathrm{aM} の$ 濃度（従来のELISA 法の検出限界の $1 / 10^{6}$ 相当）の前立腺特 異抗原の検出に成功している ${ }^{19)}$.

従来のディジタルELISAでは, 観察系として蛍光顕微鏡 が使用されているが, 顕微鏡光学系に替えて, 専用設計し たイメージセンサとレンズレス構造の光学デバイスを使用 することで, 測定システムの小型化や簡易化が可能となり, 最終的にはポータブルデバイスとしての実用化が期待でき る，筆者らは，図4に示すような反射率の高い金属による 


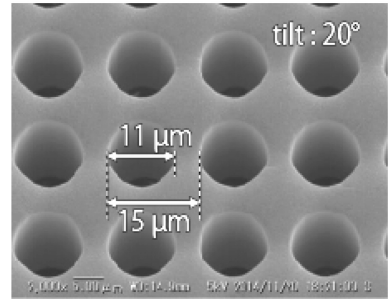

(a)

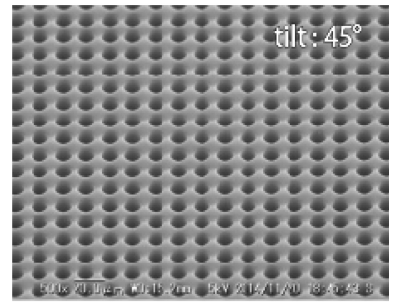

(b)
図5 Cu上に形成された開ロアレイのSEM像

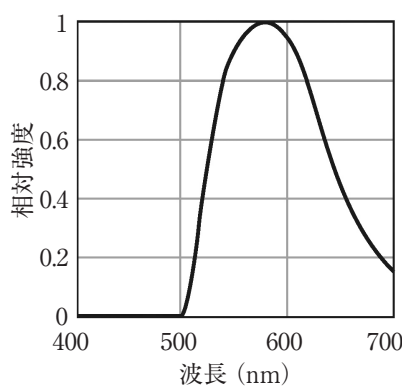

(a) 染料ドープ樹脂充填素子

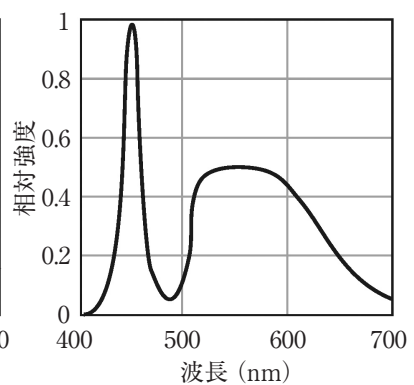

(b) 無着色樹脂充填素子
図6 試作ライトパイプアレイ素子を透過後の白色LED光源のスペクトル

パイプを形成し，励起光吸収フィルタで充填したライトパ イプアレイ構造を考案した $\left.{ }^{20)} 21\right)$. 個々のパイプをイメージ センサの画素に対応させることにより, 隣接画素への蛍光 の漏れ (クロストーク) も防ぐことができる. 金属ライトパ イプは電解めっき技術を使って形成した。金属材料は, 反 射率はやや低くなるが，電解めっきの容易さから銅 $(\mathrm{Cu})$ を選定した. 図 5 にSEM写真を示す. 厚さ $30 \mu \mathrm{m}$ の $\mathrm{Cu}$ 層 に貫通孔が開いている. 蛍光観察のため, 貫通孔には励起 光を吸収する染料をドープした樹脂を充填した。

図6は，フィルタの透過光スペクトルを取得したもので, 染料ドープ樹脂を埋め込んだライトパイプアレイを通過し た白色 LED光は, 短波長成分が除去されている. 一方, 染 料をドープしていない樹脂を埋め込んだものでは，ほぼ光 源と同じスペクトルが観測された。

ライトパイプ (マイクロピラー吸収フィルタ)アレイと蛍 光反応チャンバーアレイを形成した銅プレートを使って CMOSイメージセンサで蛍光検出を行うためには, ライト パイプアレイの開口部とCMOSイメージセンサの画素の位 置を合わせて密着させる必要がある. そのためのアライメ ント機構の試作を行った (図7).

このような微弱な蛍光検出デバイスにおいては, 励起光 成分の除去が非常に重要となる。しかし，デバイスの小型 化を実現するために蛍光フィルタ性能は制限される場合が 多く，可能であればフィルタレスであることが望ましい.
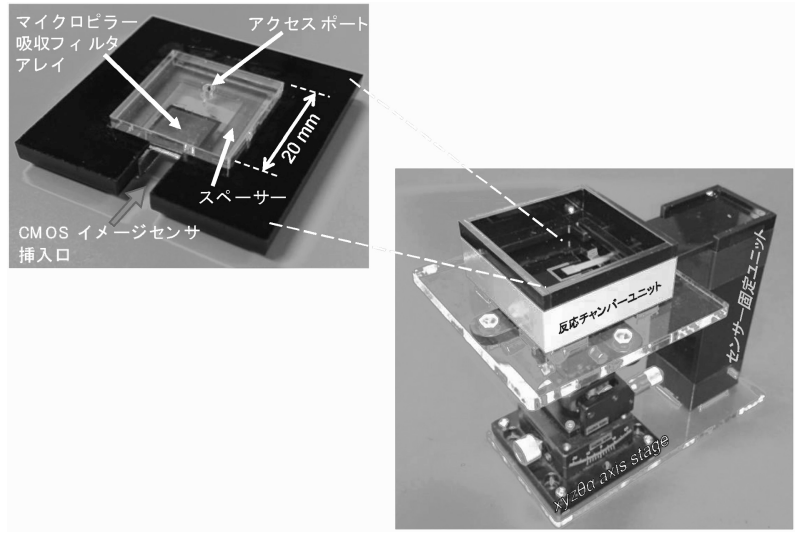

図 7 ディジタルELISAアライメントユニット試作品

前節で述べた波長分離検出可能なセンサを用いることによ り，高感度検出が実現されることが期待される。

\section{3. 生体埋植用イメージセンサ}

近年, 各国での大型な脳研究プロジェクトが推進されて いることを背景に，実験動物を用いて自由行動下での脳神 経活動等を計測し, その機能解明を目指す研究が活発と なってきている.マウスの頭部に装着して脳神経活動を観 察可能なカメラシステムも商品化されているが, 基本的に は蛍光顕微鏡を小型化したものであり，イメージセンサに 対して光学系が相対的に大きなものとなっている.これに 対して，イメージセンサを専用に設計することで，センサ および光学系の飛躍的な小型・軽量化が実現される22) 23). これにより, 生体内の観察対象領域近傍に埋植が可能とな り, 自由行動下での実験への適用が容易になる。本節では, 生体埋植型イメージセンサについて述べる.

3.1 生体埋植用イメージセンサの構造

図8に生体埋植型イメージセンサの写真を示す。このセ ンサは埋植された動物の行動実験を想定し，なるべく行動

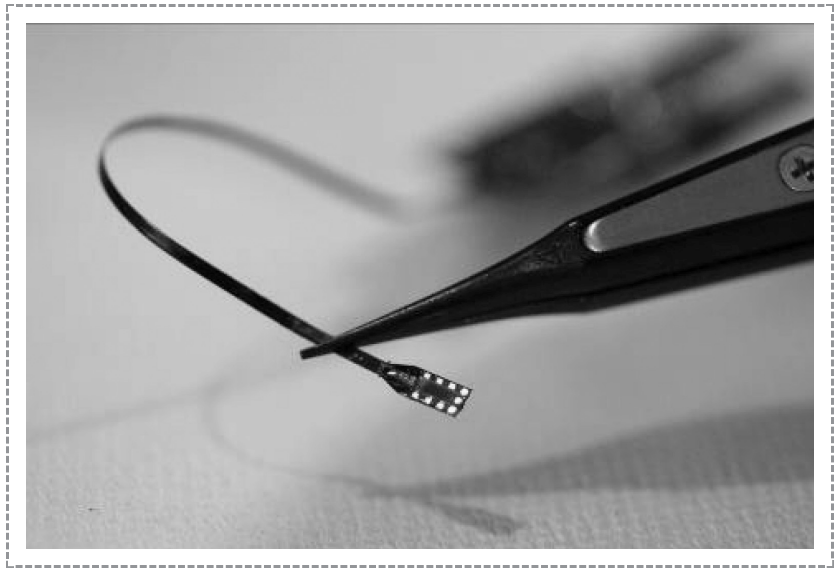

図8 生体埋植型イメージングデバイス外観 


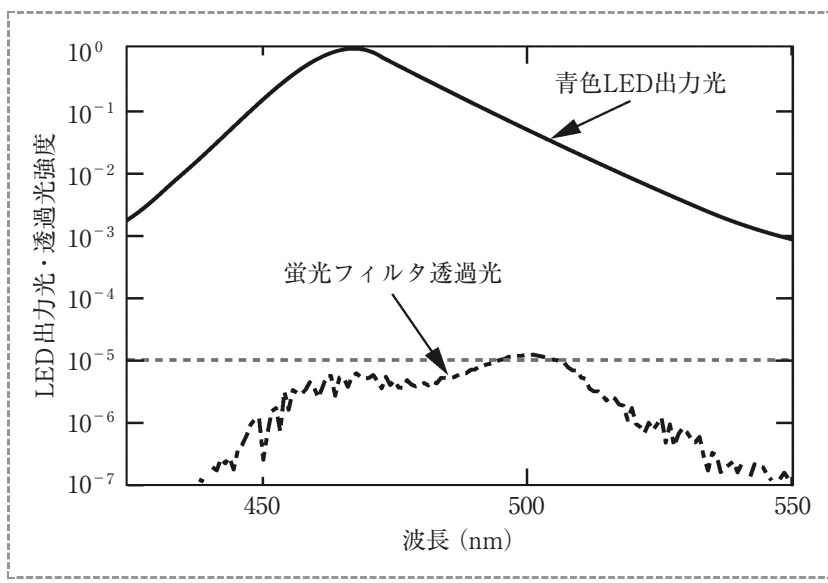

図9 青色LEDおよび試作フィルタ透過光のスペクトル

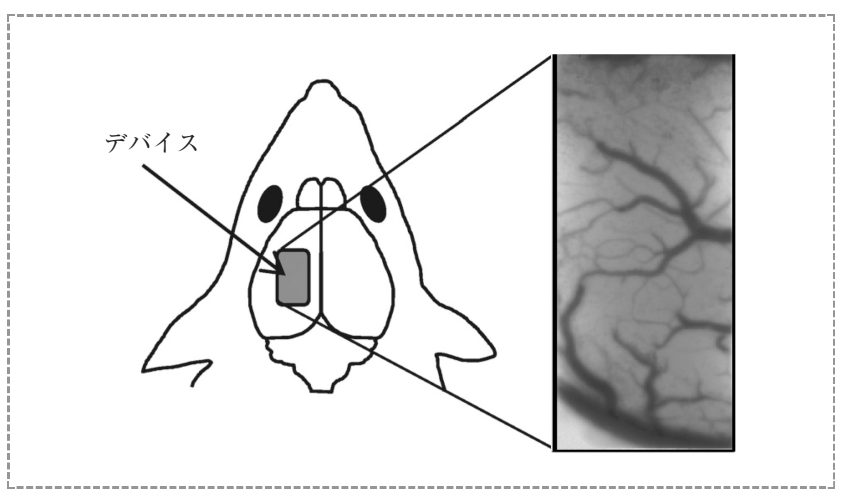

図 10 生体埋植型デバイスによる脳表撮像例 （撮像範囲は0.9 mm × $2.0 \mathrm{~mm}$ )
の妨げとならないように配線数を 4 本としている.イメー ジセンサは, 研磨により $150 \mu \mathrm{m}$ に薄型化し, 用途に応じ て蛍光フィルタを画素アレイ上に搭載している. また， セ ンサ周囲にLEDを配置している。

\section{2 蛍光観察用フィルタ}

一般的に蛍光観察においては, 蛍光物質に対して, エネ ルギーを与える励起光と比較して蛍光の強度が非常に低い ため, 波長選択性の高いフィルタによって励起光除去が行 われる. 蛍光顕微鏡では, 誘電体多層膜による干渉フィル 夕が用いられることが多いが, 干渉フィル夕は入射光角度 によって透過波長が変化する。しかし, 生体埋植型のイ メージセンサでは, 生体内で光が散乱し, さまざまな方向 からセンサへ入射することが想定される. そのため, 透過 スペクトルに角度依存性のない吸収型フィル夕を用いる必 要がある。

また，コンタクトイメージングではフィルタ厚が空間分 解能の低下につながる. 薄膜で充分な波長選択性能を得る ためには，高い色素濃度のフィルタが要求される.

筆者らのグループでは, 緑色蛍光タンパク質に代表され る緑色蛍光用のフィルタとして, 染料系の黄色色素を用い たフィルタを試作した ${ }^{24)}$. 有機溶媒に溶解させ, 光学用樹 脂と混合することで，スピンコート法によるセンサ上への 直接塗布や転写が可能となる。

図9に試作したフィルタを用いたLED出力の透過スペク トルを示す. 青色 LED は, 発光波長幅が広くGFP蛍光の スペクトルと重なってしまうため, イメージセンサ用の青 色レジストを励起光フィルタとして用いた. 透過光のピー クが $10^{-5}$ 程度となっており, 高い励起光除去性能が達成 されている.

\section{3 内因性信号イメージング}

脳神経活動の直接的な観察には, 神経細胞を蛍光色素で染 色する方法や蛍光タンパクを発現させる方法が有効である. しかし, 脳活動が活性化されている領域では血流量などが 変化し, 間接的に脳活動を光学観察することができる.こ
のような信号は内因性信号と呼ばれる，本手法は，染色な どを行う必要がない。また, 蛍光色素のように連続した光 照射によって応答が減少するようなこともなく, 実験が比 較的容易である。一方で, 応答が遅く, 空間分解能は低い。

筆者らは，内因性信号イメージング用の生体埋植型イメー ジセンサデバイスを試作した ${ }^{25)}$ 26)．本デバイスは，脳表に 配置することで観察を行う。励起光源として, 緑色LEDを 搭載している。緑色の波長帯は，へモグロビンによる吸収 がきく，血流が鮮明に撮像できる．本デバイスでは，脳に 照射された光が脳内で散乱・吸収された結果として，セン サ面に到達した光分布を観察するため, 蛍光センサのよう なフィルタは搭載していない。 また, 刺入型デバイスと同 様，レンズは搭載せず，コンタクトイメージングを行う.

図10に試作したデバイスによって, 脳表を撮像した結果 を示す。観察対象にはラット成体を用いた（動物実験は, 奈良先端科学技術大学院大学の動物実験に関する規定に基 づいて行った)。へモグロビンによる照射光の吸収により， 血管が暗く観察されている. 図11 は，あるフレームを参 照像として差分を取得した結果である。血管内のへモグロ ビン濃度の差から血流を動画像として得ることに成功して いる.

上述のデバイスでは, 緑色光を照射し, へモグロビン濃 度による吸収分布を観察した、へモグロビンは酸化・還元 によって吸収スペクトルが変化することから，より長波長 の光源を用いて観察することで，これらの情報も取得する ことが可能となる。しかし, 吸収率が低く, 微弱な輝度変 化を検出する必要があることから, 高いSN比が要求される. このような条件では, SN比は光ショットノイズによって制 限され, 高 SN比化には飽和光量を高くすることが要求され る。これに対し，筆者らのグループでは，自己リセット機 能を有する画素を用いることを提案している ${ }^{27)}$ 28)．自己リ セットにより，画素飽和を回避することが可能である。ま た，画素内にキャパシタを配置することによって，飽和容 量を高くした画素も提案されている ${ }^{29)}$. 照射可能光量と要 


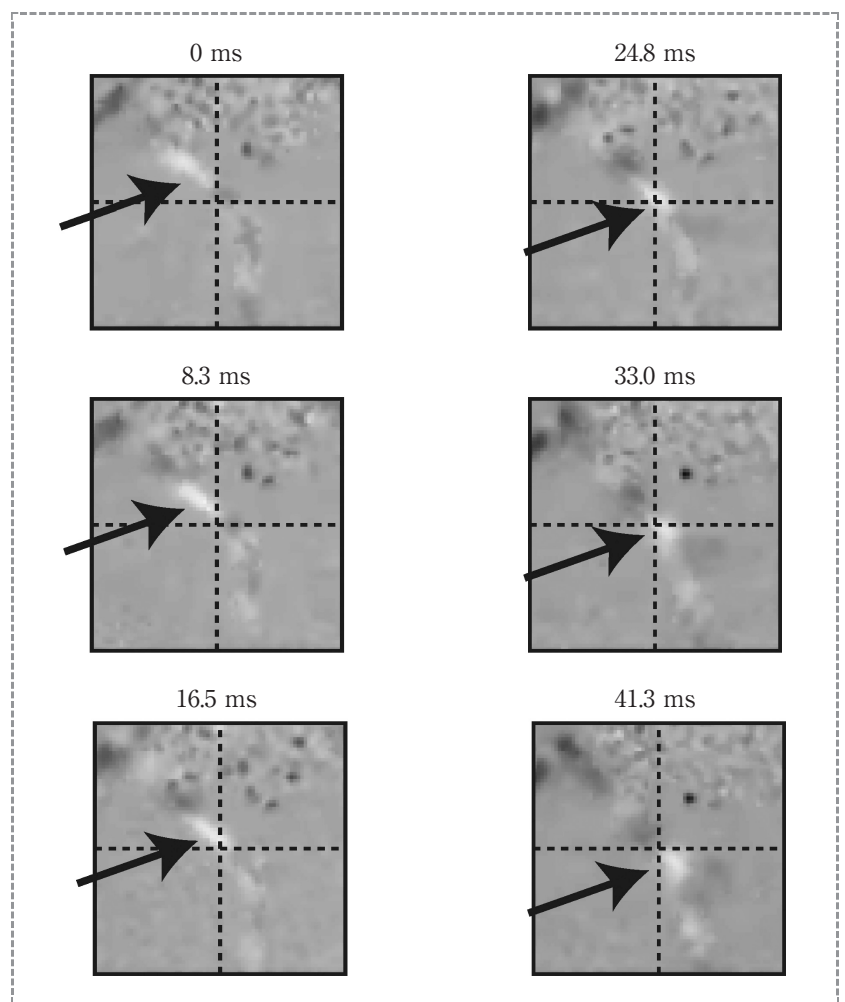

図 11 埋植型イメージングデバイスによる脳表血流イメージング例

求されるSN比によっては，有効な手法と考えられる。

\section{4. むすび}

バイオイメージング分野における技術動向について概説 し，筆者らのグループで研究を進めているデバイスについ て例示した.イメージセンサを専用に設計することにより， 従来法では撮像不可能な現象への適用が可能になる。本稿 では紹介していないが，CMOSセンサ技術は光学的なイ メージングだけでなく，イオン分布のイメージング技術へ も展開されている. これらの技術が, 今後の生物学や医学 の発展に寄与するものと期待される． (2015年12月1日受付)

\section{〔文 献〕}

1) J. Ma and E.R. Fossum: "A pump-gate jot device with high conversion gain for a quanta image sensor", IEEE J. Electron. Dev., 3, 2, pp.73-77 (2015)

2) F. Kusuhara, S. Wakashima, S. Nasuno, R. Kuroda and S. Sugawa: "Analysis and reduction of floating diffusion capacitance components of CMOS image sensor for photon-countable sensitivity", Proc. International Image Sensor Workshop 2015 (June 2015)

3) S. Wakashima, F. Kusuhara, R. Kuroda and S. Sugawa: "A linear response single exposure CMOS image sensor with $0.5 \mathrm{e}^{-}$readout noise and $76 \mathrm{ke}^{-}$full well capacity", 2015 Symp. VLSI Circuit, C88-89 (June 2015)

4) J. Ma and E. Fossum: "Quanta image sensor jot with sub $0.3 \mathrm{e}^{-} \mathrm{rms}$ read noise and photon counting capability", IEEE Electron Dev. Lett., 36, 9, pp.926-928 (Sep. 2015)

5) M.-W. Seo, S. Kawahito, K. Kagawa and K. Yasutomi: "A 0.27 e-rms read noise $220 \mu \mathrm{V} / \mathrm{e}^{-}$conversion gain reset-gate-less CMOS image sensor with $0.11 \mu \mathrm{m}$ CIS process", IEEE Electron Dev. Lett., 36, 12, pp.1344-1347（Dec. 2015）
6) C. Veerappan, J. Richardson, R. Walker, D.-U. Li, M.W. Fishburn, Y. Maruyama, D. Stoppa, F. Borghetti, M. Gersbach, R.K. Henderson, E. Charbon: "A $160 \times 128$ single-photon image sensor with on-pixel 55ps 10b time-to-digital converter", 2011 ISSCC Tech. Dig. Papers, pp.312314 (Feb. 2011)

7) L. Pancheri, N. Massari and D. Stoppa: "SPAD image sensor with analog counting pixel for time-resolved fluorescence detection", IEEE Trans. Electron Dev., 60, 10, pp.3442-3449 (2013)

8) H.-J. Yoon, S. Itoh and S. Kawahito: "A CMOS image sensor with inpixel two-stage charge transfer for fluorescence lifetime imaging", IEEE Trans. Electron Dev., 56, 2, pp.214-221 (2009)

9) Z. Li, S. Kawahito, K. Yasutomi, K. Kagawa, J. Ukon, M. Hashimoto, H. Niioka: "A time-resolved CMOS image sensor with draining-only modulation pixels for fluorescence lifetime imaging", IEEE Trans. Electron Dev., 59, 10, pp.2715-2722 (2012)

10) M.W. Seo, K. Kagawa, K. Yasutomi, T. Takasawa, Y. Kawata, N. Teranishi, Z. Li, I.A. Halin and S. Kawahito: "A 10.8 ps-timeresolution $256 \times 512$ image sensor with 2-Tap true-CDS lock-in pixels for fluorescence lifetime imaging", 2015 ISSCC Tech. Dig. Papers, pp.198-199 (Feb. 2015)

11) Z. Li, S. Kawahito, K. Yasutomi, K. Kagawa, J. Ukon, M. Hashimoto and H. Niioka: "A time-resolved CMOS image sensor with drainingonly modulation pixels for fluorescence lifetime imaging", IEEE Trans. Electron Dev., 59, 10, pp.2715-2722 (2012)

12) R. Merrill: "Color separation in an active pixel cell imaging array using a triple-well structure:" US Pat. 5,965,875 (1999)

13) Y. Maruyama, K. Sawada, H. Takao and M. Ishida: "A novel filterless fluorescence detection sensor for DNA analysis", IEEE Trans. Electron Dev., 53, 3, pp.553-558 (2006)

14) K. Yamasaki, H. Nakazawa, N. Misawa, M. Ishida and K. Sawada: "Multicolor fluorescence detection for single nucleotide polymorphism genotyping using a filter-less fluorescence detector", Appl. Phys. Lett., 102, 23233701 (2013)

15) H. Nakazawa, K. Yamasaki, T. Toyofuku, I. Akita, M. Ishida and K. Sawada: "Improvement of the detection accuracy and detection limit of a filter-less fluorescence detector", Appl. Phys. Express, 6, 7, 077001 (2013)

16) Y. Moriwaki, K. Takahashi, I. Akita, M. Ishida and K. Sawada: "Improvement of dynamic range of filter-less fluorescence sensor with body-biasing technique", Jpn.J. Appl. Phys., 54, 4S, 04DL03 (2015)

17) H. Takehara, K. Miyazawa, T. Noda, K. Sasagawa, T. Tokuda, S.H. Kim, R. Iino, H. Noji and J. Ohta: "A CMOS image sensor with stacked photodiodes for lensless observation system of digital enzyme-linked immunosorbent assay", Jpn.J. Appl. Phys., 53, 4S, 04EL02 (2014)

18) D.M. Rissin, C.W. Kan, T.G. Campbell, S.C. Howes, D.R. Fournier et al.: "Single-molecule enzyme-linked immunosorbent assay detects serum proteins at subfemtomolar concentrations", Nat. Biotechnol., 28, 6, pp.595-599 (June 2010)

19) S.H. Kim, S. Iwai, S. Araki, S. Sakakihara, R. Iino and H. Noji: "Largescale femtoliter droplet array for digital counting of single biomolecules", Lab Chip, 12, 23, pp.4986-4991 (Dec. 2012)

20) H. Takehara, M. Nagasaki, K. Sasagawa, H. Takehara, T. Noda, T. Tokuda and J. Ohta: "Micro-lihgt-pipe array with an excitation attenuation filter for lensless digital enzyme-linked immunosorbent assay", Jpn.J. Appl. Phys., 55, 3S2, 03 DF03 (2016)

21)H. Takehara, M. Nagasaki, K. Sasagawa, H. Takehara, T. Noda, T. Tokuda and J. Ohta: "High coupling efficiency contact imaging system having micro light pipe array for a digital enzyme-linked immunosorbent assay", 2015 IEEE BioCAS, C5L-A-2 (Oct. 2015)

22) J. Ohta, T. Tokuda, K. Sasagawa and T. Noda: "Implantable CMOS biomedical devices", Sensors, 9, 11, pp.9073-9093 (2009)

23) J. Ohta, A. Tagawa, T. Kobayashi, T. Noda, K. Sasagawa and T. Tokuda: "Implantable distributed biomedical photonic devices", Sensors and Materials, 23, 7, pp.369-379 (2011) 
24) Y. Sunaga, M. Haruta, H. Takehara, Y. Ohta, M. Motoyama, T. Noda, K. Sasagawa, T. Tokuda and J. Ohta: "Implantable CMOS imaging device with absorption filters for green fluorescence imaging", Proc. SPIE, 8928, 89280L (Mar. 2014)

25) M. Haruta, C. Kitsumoto, Y. Sunaga, H. Takehara, T. Noda, K. Sasagawa, T. Tokuda and J. Ohta: "An implantable CMOS device for blood-flow imaging during experiments on freely moving rats", Jpn.J. Appl. Phys., 53, 4S, 04EL05 (2014)

26) M. Haruta, Y. Sunaga, T. Yamaguchi, H. Takehara, T. Noda, K. Sasagawa, T. Tokuda and J. Ohta: "Intrinsic signal imaging of brain function using a small implantable CMOS imaging device", Jpn.J. Appl. Phys., 54, 4S, 04DL10 (2015)

27) T. Yamaguchi, Y. Sunaga, M. Haruta, H. Takehara, T. Noda, K. Sasagawa, T. Tokuda and J. Ohta: "Improvement of power consumption and SNR of self-reset pixels for an implantable CMOS image sensor", 2015 SSDM Tech. Dig. Papers, F-2-3 (Sep. 2015)

28) K. Sasagawa, T. Yamaguchi, S. Member, M. Haruta, Y. Sunaga, H. Takehara, H. Takehara, T. Noda, T. Tokuda and J. Ohta: "An implantable CMOS image sensor with self-reset pixels for functional brain imaging", IEEE Trans. Electron. Dev., 63, 1, pp.214-222 (Jan. 2016)

29) G. Meynants, X. Wu, S. Van Hoogenbemt, T. De Ridder, P. De Wit, K. Ruythooren, K. Van Esbroeck: "700 frames/s 2 MPixel global shutter image sensor with $2 \mathrm{Me}^{-}$full well charge and $12 \mu \mathrm{m}$ pixel pitch", Proc. IISW 2015 (June 2015)
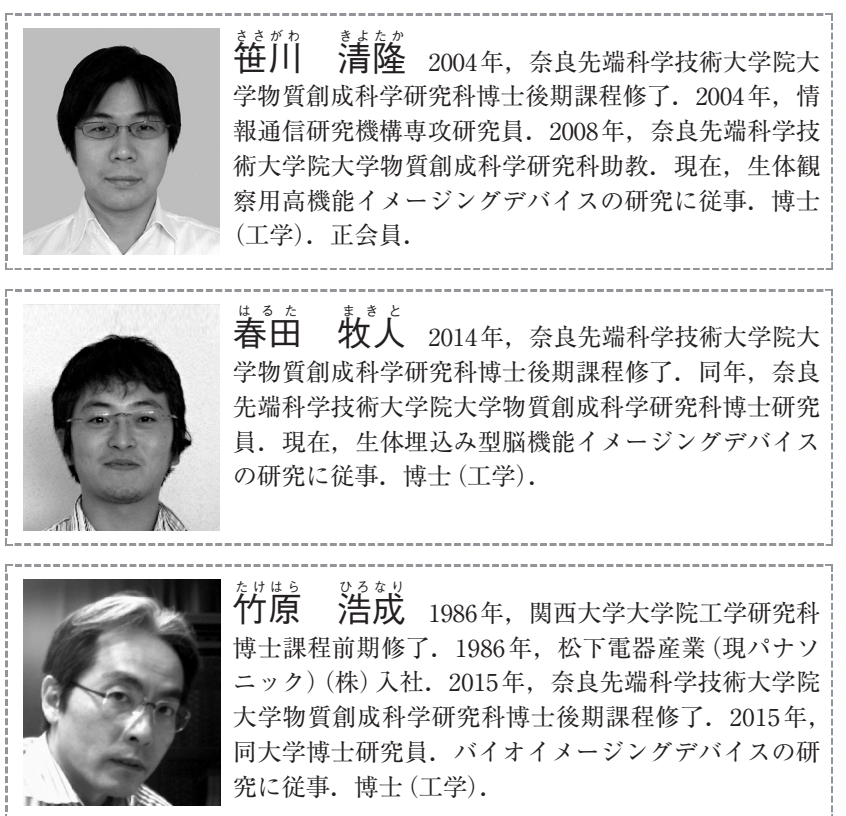

竹原浩成 1986年, 関西大学大学院工学研究科 博士課程前期修了. 1986年, 松下電器産業 (現パナソ ニック) (株) 入社. 2015 年，奈良先端科学技術大学院 大学物質創成科学研究科博士後期課程修了. 2015年, 同大学博士研究員. バイオイメージングデバイスの研 究に従事. 博士 (工学).
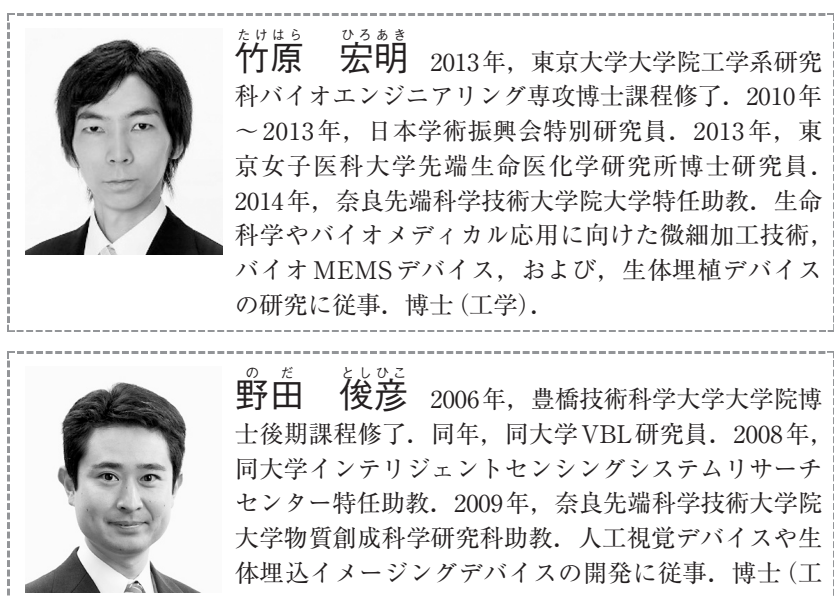

野田 俊彦 2006年, 豊橋技術科学大学大学院博 士後期課程修了．同年，同大学 VBL研究員. 2008年, 同大学インテリジェントセンシングシステムリサーチ センター特任助教. 2009年, 奈良先端科学技術大学院 大学物質創成科学研究科助教. 人工視覚デバイスや生 体埋込イメージングデバイスの開発に従事. 博士 (工 学). 正会員.

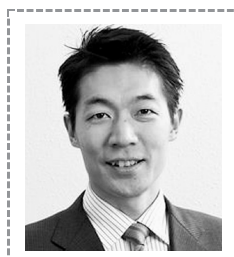

德田㔖 1998 年, 京都大学大学院工学研究科 博士後期課程修了. 1998年，日本学術振興会特別研究 員 (PD). 1999年, 奈良先端科学技術大学院大学物質 創成科学研究科助手. 2008 年, 同大学准教授. 半導体 フォトニクスデバイス, 特にバイオイメージングデバ イス，ニューロエレクトロニクスデバイスの研究に従 事. 博士 (工学). 正会員.

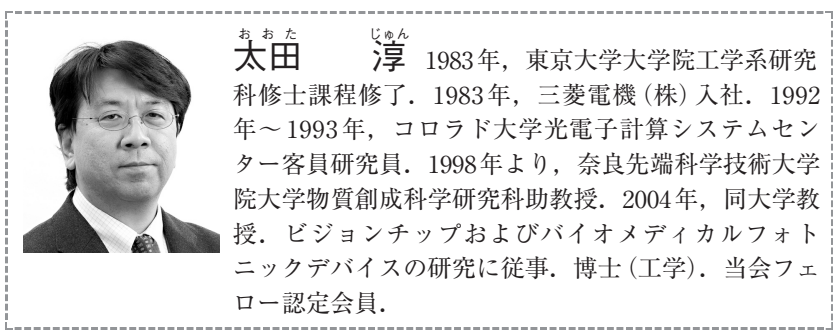

